AperTO - Archivio Istituzionale Open Access dell'Università di Torino

\title{
Scientists' warning on the conservation of subterranean ecosystems
}

\section{This is the author's manuscript}

Original Citation:

\section{Availability:}

This version is available http://hdl.handle.net/2318/1701701

since 2019-05-13T10:14:05Z

Published version:

DOI:10.1093/biosci/biz064

Terms of use:

Open Access

Anyone can freely access the full text of works made available as "Open Access". Works made available under a Creative Commons license can be used according to the terms and conditions of said license. Use of all other works requires consent of the right holder (author or publisher) if not exempted from copyright protection by the applicable law. 


\section{Scientists' warning on the conservation of subterranean ecosystems}

Stefano Mammola ${ }^{1,2,3, *}$, Pedro Cardoso ${ }^{2,3}$, David C. Culver ${ }^{4}$, Louis Deharveng ${ }^{5,6}$, Rodrigo L. Ferreira $^{6,7}$, Cene Fišer ${ }^{6,8}$, Diana M. P. Galassi ${ }^{6,9}$, Christian Griebler ${ }^{10,11}$, Stuart Halse ${ }^{12}$, William F. Humphreys $^{6,13}$, Marco Isaia $^{1,3}$, Florian Malard ${ }^{14}$, Alejandro Martinez ${ }^{15}$, Oana T. Moldovan ${ }^{6,16}$, Matthew L. Niemiller ${ }^{17}$, Martina Pavlek ${ }^{18,19}$, Ana Sofia P. S. Reboleira ${ }^{6,20}$, Marconi Souza-Silva ${ }^{7}$, Emma C. Teeling ${ }^{21}$, J. Judson Wynne ${ }^{6,22}$, Maja Zagmajster ${ }^{6,8}$

1. Department of Life Sciences and Systems Biology, University of Turin, Turin, Italy

2. LIBRe - Laboratory for Integrative Biodiversity Research, Finnish Museum of Natural History, University of Helsinki, Helsinki, Finland

3. IUCN SSC Spider and Scorpion Specialist Group

4. Department of Environmental Science, American University, Washington, DC, United States of America

5. Institut de Systématique, Evolution, Biodiversité (ISYEB), CNRS UMR 7205, MNHN, UPMC, EPHE, Museum national d'Histoire naturelle, Sorbonne Université, Paris, France

6. IUCN SSC Cave Invertebrate Specialist Group

7. Center of Studies in Subterranean Biology, Biology Department, Federal University of Lavras, Lavras, Brazil

8. SubBio Lab, Department of Biology, Biotechnical Faculty, University of Ljubljana, Ljubljana, Slovenia

9. Department of Life, Health and Environmental Sciences, University of L'Aquila, L'Aquila, Italy 10. Helmholtz Zentrum München, Institute of Groundwater Ecology, Neuherberg, Germany

11. Division of Limnology, Center of Functional Ecology, University of Vienna, Vienna, Austria

12. Bennelongia Environmental Consultants, Jolimont, Australia

13. School of Biological Sciences, University of Western Australia, Crawley, Australia

14. Univ Lyon, Université Claude Bernard Lyon 1, CNRS UMR 5023, ENTPE, Laboratoire d'Ecologie des

Hydrosystèmes Naturels et Anthropisés, Villeurbanne, France

15. INRA - Institute for Water Research, Consiglio Nazionale delle Ricerche, Verbania, Italy

16. Emil Racovitza Institute of Speleology, Cluj-Napoca, Romania

17. Department of Biological Sciences, The University of Alabama in Huntsville, Huntsville, Alabama, USA

18. Department of Evolutionary Biology, Ecology and Environmental Sciences \& Biodiversity Research Institute, University of Barcelona, Barcelona, Spain

19. Croatian Biospeleological Society, Zagreb, Croatia

20. Natural History Museum of Denmark, University of Copenhagen, Copenhagen, Denmark 
40 21. School of Biology and Environmental Science, University College Dublin, Ireland.

41 22. Department of Biological Sciences, Merriam-Powell Center for Environmental Research,

42 Northern Arizona University, Flagstaff, USA

43 *Corresponding author: stefanomammola@gmail.com

45 Word Count: 3879 (Main text \& Acknowledgments) - $\mathbf{N}^{\circ}$ reference: 80

\section{ABSTRACT}

47 In light of recent alarming trends in human population growth, climate change and other 48 environmental disturbances, a 'Warning to Humanity' manifesto was published in BioScience in 49 2017. This call reiterated most of the ideas originally expressed by the Union of Concerned 50 Scientists in 1992, including the fear that we are "[...] pushing Earth's ecosystems beyond their 51 capacities to support the web of life." As subterranean biologists, we take this opportunity to 52 emphasize the global importance and the conservation challenges associated with subterranean 53 ecosystems. They likely represent the most widespread non-marine environments on Earth, yet 54 specialized subterranean organisms remain among the least documented and studied. Largely 55 overlooked in conservation policies, subterranean habitats play a critical functional role in the 56 functioning of the web of life and provide important ecosystem services. We highlight main threats to subterranean ecosystems and propose a set of effective actions to protect this globally important 58 natural heritage.

\section{Keywords}

61 Biodiversity crisis, Caves, Extinction risk, Groundwater, Nature conservation 
"Human beings and the natural world are on a collision course."

83 Building on the manifesto "World Scientists' Warning to Humanity" issued in 1992 by the Union of 84 Concerned Scientists, Ripple et al. (2017) recently published a passionately debated paper titled "World Scientists' Warning to Humanity: a Second Notice." This novel proclamation, which was endorsed by more than 15,000 cosignatory scientists ("Alliance of World Scientists"), reiterated most of the ideas and concerns presented in the first manifesto, and in particular the fear that humans are "[...] pushing Earth's ecosystems beyond their capacities to support the web of life." The second notice highlighted alarming trends in several environmental issues over the last 25 years (1992-2016), including global climate change, deforestation, biodiversity loss, human population increase, and a decline in freshwater resources.

Since its publication, this second notice has been extensively discussed in the scientific literature and social media, stimulating an upsurge of discipline-specific follow-up articles focused on particular biological or social systems (Ripple W.J. [Oregon State University, Corvallis, United States], personal communication, 7 September 2018). As a group of subterranean biologists with a breadth of different expertise and a strong commitment to biodiversity conservation, we take this opportunity to examine some alarming trends underscored by the Alliance of World Scientists from a "subterranean" perspective. We discuss the implications that this Ripple et al. (2017)' manifesto has for the conservation of the subterranean realm, which includes some of the most unique, secluded, understudied, and difficult-to-study environments on our planet. Although subterranean habitats are not at the forefront of one's mind when thinking about global conservation issues, they support exceptional forms of life and represent critical habitats to be preserved and prioritized in conservation policies. While some conservation efforts have been devoted to protect subterranean ecosystems at a local level, no global assessment has been conducted that explicitly takes these 
113 In the era of drones, satellites, and remote sensing technology, most of the accessible places on 114 Earth have been directly or indirectly mapped and explored. A remarkable exception to the 115 geographic knowledge of our planet comes from the subterranean world, which is therefore

common conservation concerns that affect all biological systems, many of them are more acute and visible in the subterranean realm and are emphasized in this contribution.

\section{CHALLENGES OF PROTECTING THE UNKNOWN} recognized as one of the most important frontiers of modern explorations (Ficetola et al. 2019). Subterranean ecosystems are likely the most widespread non-marine environments on Earth. For example, more than 50,000 caves have been documented in the United States, with nearly 10,000 known from the state of Tennessee alone (Niemiller and Zigler 2013), and some 25,000 caves are estimated solely for the Dinarides, a $60,000 \mathrm{~km}^{2}$ European karst region that is considered to be the world's most significant area of subterranean fauna radiation (Zagmajster et al. 2010). However, subterranean ecosystems are by no means restricted to those subterranean voids that we have mapped and listed in speleological cadasters (i.e. caves). In fact:

i) most subterranean voids have no entrances that are accessible to humans (Curl 1958);

ii) the small and non-accessible network of underground voids and fissures is almost limitless and this network (rather than caves) represents the elective habitat for most specialized subterranean biota (Howarth 1983);

iii) groundwater, i.e. water in the voids in consolidated and unconsolidated rocks, comprises $95 \%$ of global unfrozen fresh water and hosts organisms specialized to survive at limits of life (Fišer et al. 2014), as well as more numerous species that are important to maintaining groundwater quality (Griebler et al. 2014);

3 iv) anchialine ecosystems, represented by coastal, tidally influenced, subterranean estuaries located within crevicular and cavernous terrains, represent a specialized habitat straddling the border between subterranean freshwater and marine environments and host a specialized subterranean fauna (Bishop et al. 2015); 
137 v) a variety of superficial underground habitats, collectively termed shallow subterranean habitats,

138 support an extensive array of subterranean biota (Culver and Pipan 2014); and

139 vi) if one would be keen to account also for microbial life, a large amount of continental prokaryotic 140 biomass and as yet an unknown prokaryote diversity is hidden within these systems (Magnabosco et 141 al. 2018).

Paradoxically, although habitats beneath the Earth's surface are more widespread and 144 diversified than is usually perceived, most of them cannot be mapped and directly studied, either 145 because they are too deep or because they are hardly accessible to humans due to their millimetre 146 scale resolution. Consequently, specialized subterranean organisms remain among the least 147 documented fauna on our planet. This impediment, recently termed "Racovitzan shortfall" (Ficetola 148 et al. 2019), poses a thorny question: if the real extension of the subterranean domain is unknown, 149 and the biota we observe in a cave are just the "tip of the subterranean biodiversity iceberg", what can we practically do to protect the full extent of subterranean habitats and their inhabitants?

To make sound decisions for the conservation of the subterranean world, there is first an urgent need to accelerate scientific research, aiming at exploring subterranean biodiversity altogether with the abiotic and biotic factors that drive its distribution patterns across space and time. Available estimates (Culver and Holsinger 1992; Zagmajster et al. 2018) suggest that most obligate subterranean species worldwide have not yet been described (i.e., the Linnean shortfall). In the epoch of sixth mass extinction crisis, many of these species may face extinction before they are discovered and formally described - a phenomenon described by Wilson (1992) as 'Centinelan extinctions'. Moreover, several other knowledge gaps impede our ability to protect and conserve subterranean biodiversity (Table 1). The distribution (i.e., the Wallacean shortfall) and the life history of most described subterranean species in particular, are virtually unknown. Acquiring basic

161 knowledge about biological and functional diversity of subterranean organisms (i.e., the Raunkiæran shortfall), their phylogenetic relationships (i.e., the Darwinian shortfall), their interactions within different subterranean communities (i.e., the Eltonian shortfall), as well as their sensitivity to environmental perturbations (i.e., the Hutchinsonian shortfall), represent pivotal steps toward consolidating scientific knowledge to support conservation planning (Cardoso et al. 2011a; Diniz-Filho et al. 2013; Hortal et al. 2015) and further emphasizing the ecosystem services that the subterranean fauna provide. 
171 The first argument emphasizing the importance of protecting subsurface ecosystems emerges when

172 considering the fascinating evolutionary changes many animals have undergone to become adapted 173 to underground life. Subterranean species are astonishing and bizarre outcomes of evolution (Figure 174 1), and subterranean habitats represent sources of unexpected, oftentimes serendipitous, scientific 175 discoveries. The study of these remarkable species allows us to travel outside the limits of our own 176 imagination, exploring unique biological adaptations (e.g., Soares and Niemiller 2013, Yoshizawa 177 et al. 2014, 2018a), learning about fundamental ecological and evolutionary processes (Juan et al. 178 2010, Mammola 2018), and even gaining insights into human health (e.g., Riddle et al. 2018, 179 Yoshizawa et al. 2018b).

180 Furthermore, being intimately interconnected with both the soil and surface systems, 181 subterranean systems play a critical role in the regulation and provision of ecosystem services and 182 in the functioning of the web of life. Therefore, the survival of humankind is likely to be more 183 dependent on maintenance of healthy subterranean environments than generally recognized. For 184 example, the riparian surface communities and the life cycles of cave-dwelling organisms such as 185 bats, critically depend on intact connections with the underlying subterranean compartments.

Over $20 \%$ of all living mammals on earth are bats $(n \sim 1,300)$, with a huge number of species considered as 'cave-dependent' (e.g., ca. 46\% bat species North America; 70\% Europe; 45\% Mexico; 77\% China); bats use caves as day-roosts, maternity colonies, hibernation sites, and as swarming/mating locations (Furey and Racey 2016, Medellin et al. 2017, Teeling et al. 2018). Their heir persistence depends on the occurrence of natural caves, which can also limit their occurrence on the landscape (Furey and Racey 2016). For example, the charismatic, enigmatic and endangered

192 bumble-bee bat (Craseonycteris thonglongyai), which is considered world's smallest mammal, is 193 strictly restricted to the karst landscape region $\sim 2,000 \mathrm{~km}^{2}$ straddling the Thai-Myanmar border 194 (Puechmaille et al. 2011). As major arthropod predators, bats have been shown to be keystone species ensuring optimal ecosystem functioning across multiple trophic levels (Kunz et al. 2011).

They provide vital ecosystem services including insect pest suppression, pollination and seed dispersal of forest plants and trees, and pollination of important food crops. As many bat 198 species feed on crop pests, the cost of managing and controlling these arthropod pest species in the 199 U.S. without bats, is estimated between $\$ 3.7$ and $\$ 53$ billion/year (Boyles et al. 2011). Many 200 insectivorous bat species feed on disease vector biting-insects that plague humans and livestock, 201 including mosquitoes known vectors of numerous life-threatening human and livestock diseases 202 including Malaria, Zika and West Nile virus (e.g., Caraballo and King 2014, Boyer et al. 2018), as 203 well as aphids that spread plant pathogens ( $\mathrm{Ng}$ and Perry 2004), and botflies that parasitize both 
humans and livestock. Bats, including many cave roosting species, are documented as both

205 pollinators and seed dispersers in forests, mangroves and deserts (e.g., Valiente-Banuet et al. 1996,

206 Medellín and Gaona 1999, Azuma et al. 2002, Kunz et al. 2011). Cave-roosting nectar-feeding bats

207 in the southwestern U.S. and northern Mexico are primary pollinators for columnar cacti, including

208 the iconic Saguaro cacti (Carnegiea gigantea), which are considered keystone species of the

209 Sonoran Desert (Valiente-Banuet et al. 1996). Additionally, cave roosting nectar-feeding bats have

210 coevolved to pollinate agave, also a keystone species in Mexican deserts and scrub forests and a key

211 ingredient in tequila - production of this beverage employs 70,000 people and garners 1.2 billion

212 dollar/ year in exports alone (Trejo-Salazar et al. 2016). Another lucrative multimillion dollar

213 industry, the durian fruit of southeast Asia is primarily pollinated by a cave roosting bat species

214 (Bumrungsri et al. 2009, Stewart and Dudash 2017). Therefore, bats' role in maintaining the quality

215 of recreational outdoor areas, limiting disease transmission to humans, livestock and agricultural

216 crops, as well as ultimately enhancing human well-being through maintaining ecosystems and

217 agribusiness, is immense. Cave-roosting bat populations and their habitats must be protected to 218 ensure these key ecological services to humans continue (Medellín et al. 2017).

219 Even more important is the role of subterranean systems as freshwater reservoirs.

220 Subterranean environments store and transmit groundwater through the void spaces created by the

221 fracturing and dissolution of (carbonate and other) rocks and unconsolidated sediments that fill river

222 valleys and large basins. It is estimated that one quarter of the human population is completely or

223 partially dependent on drinking water from aquifers (Ford and Williams 2007) and groundwater

224 also largely supports agriculture and industry (Griebler and Avramov 2015).

\section{MAIN GLOBAL THREATS TO SUBTERRANEAN BIODIVERSITY}

Subterranean environments and their biota are only superficially known (pun intended). Yet, we do know that most of the threats highlighted by Ripple et al. (2017) in their manifesto are directly affecting the subterranean domain tout court, because subterranean ecosystems are inextricably

231 linked to surface processes. For example, they depend on allochthonous energy supplies, which may 232 consist of flood detritus, guano deposition from bats, birds and crickets, or dissolved organic 233 materials in waters percolating from the surface. Thus, when humans adversely change the surface 234 environment, subterranean ecosystems will respond to those changes. Most notably, deforestation 235 (Trajano 2000, Souza-Silva et al. 2015), urbanization, agricultural, industrial, and mining activities 236 (Trajano 2000; Reboleira et al. 2011, Souza-Silva et al. 2015, Sugai et al. 2015), heavy metals and 
agrochemicals pollution (Reboleira et al. 2013, Di Lorenzo et al. 2015, 2018), non-native species

238 introductions (Howarth et al. 2007, Wynne et al. 2014), tourism (Moldovan et al. 2013), and global

239 climate change (Mammola et al. 2018) negatively affect both biodiversity and subterranean

240 ecological processes. In the following sections, we briefly discuss what we consider the most

241 challenging global threats affecting subterranean ecosystems.

\section{Habitat loss}

244 Subterranean habitat loss and degradation are occurring in many regions. In several cases, the 245 disturbance of subterranean habitats is direct, although often spatially localized. For instance, 246 quarrying and mining activities often result in removal of the karst substratum, sometimes leading 247 to removal of whole karst hills (Whitten 2009). In this respect, the open pit mining for lignite 248 provides a striking example. Worldwide about 1 billion tons of lignite are produced each year. Only 249 in Germany, one of the largest lignite producers worldwide (170 million tons/year), opencast 250 mining has altered about 200,000 hectares of land including the removal of the aquifer. Moreover, 251 as a prerequisite of opencast mining, the groundwater table in the region needs to be lowered by 252 hundreds of meters to below the mining level and consequently groundwater ecosystems are 253 systematically dewatered for entire districts or even federal states accounting for billions of $\mathrm{m}^{3}$ of 254 groundwater pumped and thousands of $\mathrm{km}^{2}$ (Grünewald 2001); a destruction of groundwater 255 habitats at an incomparable dimension. Last but not least, subsequent to mining activities, 256 dewatered zones that re-saturate characteristically bear highly acidic groundwater as a consequence 257 of long-term pyrite oxidation (Wisotzky and Obermann 2001). The impact of mining activities is 258 also evident in ferruginous landscapes in Brazil, one of the largest extractive areas in the world, 259 where hundreds of caves have been destroyed by quarrying and mine excavation and groundwater

260 has been polluted by mineral waste, heavy metals, and other contaminants (Souza-Silva et al. 2015, 261 Sugai et al. 2015).

262 Furthermore, construction activities can directly threaten subterranean ecosystems. 263 Construction of infrastructure and tunnel drilling can entirely or partially destroy subterranean 264 habitats. For example, road construction within karst areas of Slovenia has resulted in the discovery 265 of more than 350 caves, with many being completely destroyed (Knez and Slabe 2016). 266 Development along rivers and streams, such as channelizing, regulating, and damming, can result in 267 major hydrological changes and loss of habitat, especially in the hyporheic zone and the subjacent 268 aquifers (e.g., Piegay et al. 2009). Modified river flow channels interrupt the connectivity between 269 surface and subterranean water and can lower the water table; similarly, diverting river flow may 
result in both flooding or desiccation within subterranean systems, which results in direct loss of habitat.

Other large-scale human activities result in a more generalized and pervasive degradation of the subterranean environment, especially in those areas where deforestation, urbanization, and industrial activities are increasing-including, but not limited to, vast portions of Southeast Asia and South America. Deforestation, in particular, represents one of the major ecological threats to subterranean habitats (Jiang et al. 2014), especially in tropical areas (Trajano 2000). In fact, loss of surface vegetation can quickly result in habitat alterations (e.g., desertification), that may alter subterranean hydrological regimes and nutrient inputs from the surface. The resultant degradation of the subterranean environment can either reduce populations of subterranean species or result in the extinction of endemic animal populations.

\section{Groundwater overexploitation and contamination}

The decline in freshwater resources was highlighted as one of the most critical negative trends that humanity is facing (Finlayson et al. 2019, Ripple et al. 2017), which can be considered a clarion call to increase global efforts to halt and reverse the ongoing degradation of groundwater resources. Anthropogenic impacts in groundwater aquifers include local and diffuse sources of contamination (e.g., Schwarzenbach et al. 2010, Lapworth et al. 2012), overexploitation of groundwater resources (Wada et al. 2010, Gleeson et al. 2012), and climate change (see next section). Maintaining healthy groundwater communities appears to be a critical component of reducing anthropogenic impacts, given the potential ecosystem services provided by most of these organisms (Griebler and Avramov 2015). Indeed, the eventual collapse of groundwater communities would in turn hinder the selfpurifying processes provided by these organisms, thus accelerating the degradation of this precious resource.

\section{Climate change}

Climate change represents one of the most complex and challenging issues in the Anthropocene (Ripple et al. 2017), and while its effects are already visible on the surface, the impacts on subterranean systems are poorly understood. In the medium- to long-term, climate change is expected to modify both deep terrestrial (Pipan et al. 2018) and aquatic subterranean ecosystems (Taylor et al. 2013). Given that deep subterranean habitats are typically characterized by environmental stability, it has been proposed that most subterranean-adapted organisms have a reduced ability to cope with significant variation in temperature (Novak et al. 2014, Raschmanová 
et al. 2018), resulting in these species being potentially highly sensitive to climate change (Mammola et al. 2018). However, it seems there is extensive variability in thermal tolerance among species related to evolutionary history and degree of subterranean adaptation (Novak et al. 2014, Rizzo et al. 2015, Raschmanová et al. 2018). In addition to thermal stability, relative humidity deficit is another important factor for subterranean-adapted species. High water saturation of the atmosphere is essential for the survival of most terrestrial subterranean organisms (Howarth 1983). Desiccation of terrestrial habitats due to global environmental change is expected to have severe negative impacts on subterranean communities (Shu et al. 2013); some taxa may be forced to retreat to greater depths, where energy sources are usually scarcer, while others may go extinct. Moreover, climate change likely will cause indirect effects underground, such as promoting colonization and establishment by alien species (Wynne et al. 2014) and variations in external trophic inputs. Strong inference-based predictions concerning the effects of climate change on organisms dwelling in climatically stable environments represent a challenging and largely unstudied field of inquiry (Mammola 2018); because the planet is already changing due to global climate change, in-depth studies are needed to understand how these changes are affecting subterranean habitats.

\section{Intrinsic vulnerability of the subterranean fauna}

While the global issues discussed above represent the main threats to ecosystems, their impact is more profound on subterranean organisms owing to their intrinsic vulnerability. There are several reasons why subterranean fauna is vulnerable, including:

i) most subterranean species are short-range endemics with extremely restricted distributions (Trontelj et al. 2009, Eme et al. 2018). Due to this range restrictedness, geographically localized threats are much more likely to have a global effect on biodiversity, as a result of irreversible species loss, than is the case in surface systems;

ii) energy limited and stable subterranean environments have selected for long-lived species with low basic metabolisms and fecundity (Voituron et al. 2011, Fišer et al. 2013). Thus, population growth is slow resulting in population instability due to catastrophic or stochastic events; 


\section{PROPOSED ACTIONS TO ILLUMINATE RESEARCH, CONSERVATION AND}

Ripple et al. (2017) proposed several effective steps that humanity can implement to create a transition to sustainability. Their recommendations for surface environments would also aid in the preservation of the subterranean world, i.e., reversing most of the ongoing negative trends in surface ecosystems will have an immediate positive influence on the preservation of subterranean ecosystems. From a discipline-oriented perspective, subterranean biologists can identify the key requirements for the protection of subterranean habitats and also work to increase the awareness of the subterranean natural heritage amongst the general public; this hopefully will increase political commitment (see Dror 2018). General effective measures are provided below:

i) collecting the much needed information on life history, ecology, distribution, and sensitivity to environmental alterations of subterranean restricted species (see Table 1), as well as external species that depend on subterranean ecosystems, like cave-roosting bats;

ii) expanding efforts to document and monitor subterranean diversity through the use and evaluation of standardized sampling techniques (e.g., Dole-Olivier et al. 2009; Wynne et al. 2018), as well as vulnerability assessments (with adaptive management protocols) to determine threat levels to subterranean ecosystems and sensitive species populations (e.g., Di Lorenzo et al. 2018, Tanalgo et al. 2018);

ii) renewing efforts to implement direct conservation measures, prioritizing communication with political powers and public institutions to develop well-funded and well-managed 
networks of protected areas for a significant proportion of the world's subterranean hotspots of diversity. Insofar as funds invested in conservation will be limited, special efforts are needed to define priority principles and criteria for channeling conservation actions (Rabelo

iv) renewing efforts in the threat assessment of subterranean species using the International Union for Conservation of Nature (IUCN) Red List criteria. Currently very few subterranean species have been assessed ( $c a .850$ species), and the subjectivity in applying the criteria across a large diversity of taxa assessed separately by various specialists has led to numerous inconsistencies. The standardization of interpretation of criteria and implementation of clear guidelines applicable across taxa can greatly improve the current situation (Cardoso et al. 2011b), a process in which the involvement of the IUCN SSC Cave Invertebrate Specialist Group will be fundamental. Through these steps, we can improve our ability to assess the conservation status of subterranean species, as a sound basis for global and local conservation policy, as well as for designing efficient species and site conservation plans;

v) developing models to quantify the effects of global climate change on subterranean communities. Although climate change is one of the most pervasive global impacts (Ripple et al., 2017), studies on the effects of climate change on cave ecosystems are few, and their results are often inconclusive. There is an urgent need to achieve an in-depth understanding of the global change issue from a subterranean perspective, through the analyses of empirical data (Pipan et al. 2018), experiments (Rizzo et al. 2015), modeling (Mammola \& Leroy 2018), and simulation studies;

vi) promoting research into the biology and ecology of groundwater organisms so that they may act, when appropriate, as sentinel species of clean waters in water quality monitoring activities. In addition, the use of most widespread contaminants that accumulate in subterranean aquifers, e.g., fertilizers and pesticides in agricultural landscapes, should be limited and a sustainable use of groundwater promoted (Danielopol et al. 2004);

vii) in recognition of the interconnectivity of surface and subterranean compartments, it is important to implement conservation measures bridging these environments. Fostering interdisciplinary scientific cooperation will be critical, i.e., by designing specific studies 
involving broad collaborations with taxonomists, ecologists, biologists, conservation biologists, ecotoxicologists, geologists, hydrologists, and soil scientists, who typically work in surface environments;

viii) developing educational programs for both primary and secondary students and the lay public to heighten awareness regarding the sensitivity of subterranean organisms, as well as emphasizing the connection between surface and subsurface ecosystems. We recommend, together with local communities and caving associations, developing classroom curricula, subterranean-themed public exhibitions, guided and regulated outdoor activities to karst and other natural terrains (like rivers) sustaining rich subterranean habitats, and other outreach activities in areas where communities both reside and are reliant upon the subterranean environments. More broadly, social media campaigns using internet, television, radio, and print media, will heighten public awareness of subterranean environments and the unique animal communities they harbour; and

\section{EPILOGUE}

423 Although we represent a small group of scientists within the large and heterogeneous community of 424 subterranean biologists, we aimed to provide a multifaceted view of the global issues affecting the subterranean world. As we have experienced during the writing of this work, the perspective from which these issues are observed by the different authors can be quite diverse. Yet, we all agreed on the fact that these systems are poorly recognized as conservation priorities, that they provide vital ecosystem services to humankind, and that they represent a true research frontier. Most importantly, we reached a full consensus in highlighting the high vulnerability of the subterranean world and the seriousness of the threats affecting it, as well as the need of making this information available to stakeholders and the general public. Indeed, although the conservation issues we discuss are well

432 understood within our community and partially covered in the specialised literature, they have never 433 been formalised in a scientific publication written for a broader audience. As with most ecosystems 434 important to supporting both diversity and providing ecological services, we reaffirm that it is our 
435 duty to humankind and toward sustainable stewardship of our planet to develop strategies to achieve

436 their preservation.

\section{ACKNOWLEDGMENTS}

439 We are grateful to all photographers for sharing their photos of subterranean species - see captions 440 of Figure 1. Special thanks are due to Prof. William J Ripple for stimulating the writing of the paper 441 and for useful suggestions. Ana Komerički provided useful information on the IUCN SSC Cave 442 Invertebrate Specialist Group. Fundings. SM is supported by Bando per l'Internazionalizzazione 443 della Ricerca - Anno 2018 (Compagnia di San Paolo). SM and MI are supported by the project 444 "The Dark Side of Climate Change" funded by University of Turin and Compagnia di San Paolo 445 (Grant award: CSTO162355). RLF is supported by the Conselho Nacional de Desenvolvimento 446 Científico e Tecnológico (Grant process: 304682/2014-4). MP is supported by the "HiddenLife" 447 project, funded by European Commission through Horizon 2020 MSCA Individual Fellowships 448 (Grant Agreement: 749867). AM is supported by the "Ancave" project, funded by European 449 Commission through Horizon 2020 MSCA Individual Fellowships (Grant Agreement: 745530). 450 DMPG is granted by the European Commission AQUALIFE LIFE12 BIO/IT/000231 451 "Development of an innovative and user-friendly indicator system for biodiversity in groundwater 452 dependent ecosystems". FM is supported by EUR H2O'Lyon (ANR-17-EURE-0018). MZ and CF 453 are supported by Slovenian Research Agency, program "Integrative Zoology and Speleobiology" 454 (P1-0184). PC was supported by projects "Ecology and conservation of the critically endangered 455 Frade Cave Spider (Anapistula ataecina)" funded by the Mohamed bin Zayed Species Conservation 456 Fund and "Towards a sampled red list index for arachnids at a global level", funded by Chicago 457 Zoological Society's Chicago Board of Trade Endangered Species Fund. ASPSR is supported by a 458 research grant (15471) from the VILLUM FONDEN. OTM received support from the grant of 459 the Romanian Ministry of Research and Innovation, CNCS - UEFISCDI (project number: PN460 III-P4-ID-PCCF-2016-0016, within PNCDI III). 


\section{REFERENCES}

Azuma H, Toyota M, Asakawa Y, Takaso T, Tobe H. 2002. Floral scent chemistry of mangrove plants. Journal of Plant Research 115: 47-53.

Bishop RE, Humphreys WF, Cukrov N, Žic V, Boxshall GA, Cukrov M, Iliffe TM, Kršinic F, Moore WS, Pohlman JW, Sket B. 2015. 'Anchialine' redefined as a subterranean estuary in a crevicular or cavernous geological setting. Journal of Crustacean Biology 35: 511-514.

Boyer S, Calvez E, Chouin-Carneiro T, Diallo D, Failloux AB. 2018. An overview of mosquito vectors of Zika virus. Microbes and Infection 20: 646-660.

Boyles JG, Cryan PM, McCracken GF, Kunz TH 2011. Economic importance of bats in agriculture. Science 332: 41-42.

Brooks TM, Mittermeier RA, da Fonseca GA, Gerlach J, Hoffmann M, Lamoreux JF, Mittermeier CG, Pilgrim JD, Rodrigues AS. 2006. Global biodiversity conservation priorities. Science 313: 5861.

Bumrungsri S, Sripaoraya E, Chongsiri T, Sridith K, Racey PA. 2009. The pollination ecology of durian (Durio zibethinus, Bombacaceae) in southern Thailand. Journal of Tropical Ecology 25: 8592.

Caraballo H, King K. 2014. Emergency department management of mosquito-borne illness: malaria, dengue, and West Nile virus. Emergency Medicine Practice 16: 1-23.

Cardoso P, Erwin TL, Borges PA, New TR. 2011a. The seven impediments in invertebrate conservation and how to overcome them. Biological Conservation 144: 2647-2655.

Cardoso P, Borges PA, Triantis KA, Ferrández MA, Martín JL. 2011b. Adapting the IUCN Red List criteria for invertebrates. Biological Conservation 144: 2432-2440. 
493 Culver DC, Holsinger JR. 1992. How many species of troglobites are there? National Speleological 494 Society Bullettin 54: 79-80.

496 Culver DC, Pipan T. 2014. Shallow subterranean habitats: ecology, evolution, and conservation. 497 Oxford University Press.

499 Culver DC, Trontelj P, Zagmajster M, Pipan T. 2013. Paving the way for standardized and 500 comparable subterranean biodiversity studies. Subterranean Biology 10: 43-50.

501

502 Curl RL. 1958. A statistical theory of cave entrance evolution. National Speleological Society 503 Bullettin 20: 9-22.

505 Danielopol DL, Gibert J, Griebler C, Gunatilaka A, Hahn HJ, Messana G, Notenboom G, Sket B. 506 2004. Incorporating ecological perspectives in European groundwater management policy. 507 Environmental Conservation 31: 185-189.

Delić T, Trontelj P, Rendoš M, Fišer C. 2017. The importance of naming cryptic species and the conservation of endemic subterranean amphipods. Scientific Reports 7: 3391.

512 Di Lorenzo T, Di Marzio WD, Spigoli D, Baratti M, Messana G, Cannicci S, Galassi DMP. 2015.

513 Metabolic rates of a hypogean and an epigean species of copepod in an alluvial aquifer. Freshwater 514 Biology 60: 426-435.

516 Di Lorenzo T, Cifoni M, Fiasca B, Di Cioccio A, Galassi DMP. 2018. Ecological risk assessment 517 of pesticide mixtures in the alluvial aquifers of central Italy: Toward more realistic scenarios for 518 risk mitigation. Science of the Total Environment 644: 161-172. 
520 Diniz-Filho JAF, Loyola RD, Raia P, Mooers AO, Bini LM. 2013. Darwinian shortfalls in

521 biodiversity conservation. Trends in Ecology \& Evolution 28: 689-695.

522

523

Dole-Olivier MJ, Castellarini F, Coineau N, Galassi DMP, Martin P, Mori N, Valdecasas A, Gibert

J. 2009. Towards an optimal sampling strategy to assess groundwater biodiversity: comparison across six European regions. Freshwater Biology 54: 777-796.

Dror Y. 2018. Warnings without power are futile. BioScience 68: 239.

Eme D et al. 2018. Do cryptic species matter in macroecology? Sequencing European groundwater crustaceans yields small ranges but does not challenge biodiversity deteminants. Ecography 41: $424-436$.

Ficetola GF, Canedoli C, Stoch F. 2019. The Racovitzan impediment and the hidden biodiversity of unexplored environments. Conservation Biology 33: 214-216.

Finlayson CM, Davies GT, Moomaw WR, Chmura GL, Natali SM, Perry JE, Roulet N, Sutton537 Grier AE. 2019. The Second Warning to Humanity-providing a context for wetland management 538 and policy. Wetlands 39: 1-5.

Fišer C, Zagmajster M, Zakšek V. 2013. Coevolution of life history traits and morphology in female subterranean amphipods. Oikos 122: 770-778.

Fišer C, Pipan T, Culver DC. 2014. The vertical extent of groundwater metazoans: an ecological 544 and evolutionary perspective. BioScience 64: 971-979.

546 Ford DC, Williams PW. 2007. Karst hydrogeology and geomorphology. Wiley.

548 Furey NM, Racey PA. 2016. Conservation Ecology of Cave Bats. Bats in the Anthropocene: 549 Conservation of bats in a changing world. Springer. 
551 Gibert J, Deharveng L. 2002. Subterranean ecosystems: A truncated functional biodiversity. 552 BioScience 52: 473-481.

554 Gleeson T, Wada Y, Bierkens MFP, van Beek LPH. 2012. Water balance of global aquifers 555 revealed by groundwater footprint. Nature 488: 197-200.

Gonzalez BC, Martínez A, Borda E, Iliffe TM, Fontaneto D, Worsaae K. 2017. Genetic spatial 558 structure of an anchialine cave annelid indicates connectivity within - but not between - islands of 559 the Great Bahama bank. Molecular Phylogenetics and Evolution 109: 259-270.

Griebler C, Avramov M. 2015. Groundwater ecosystem services - a review. Freshwater Science 34: $562355-367$.

564 Griebler C, Malard F, Lefébure T. 2014. Current developments in groundwater ecology-from 565 biodiversity to ecosystem function and services. Current Opinion in Biotechnology 27: 159-167.

Grünewald U. 2001. Water resources management in river catchments influenced by lignite mining. Ecological Engineering 17: 143-152.

Hortal J, de Bello F, Diniz-Filho JAF, Lewinsohn TM, Lobo JM, Ladle RJ. 2015. Seven shortfalls that beset large-scale knowledge of biodiversity. Annual Review of Ecology, Evolution, and 572 Systematics 46: 523-549.

574 Howarth FG. 1983. Ecology of cave arthropods. Annual Review of Entomology 28: 365-389.

576 Howarth FG, James SA, McDowell W, Preston DJ, Imada CT. 2007. Identification of roots in lava 577 tube caves using molecular techniques: implications for conservation of cave arthropod faunas. 578 Journal of Insect Conservation 11: 251-261.

580 Jiang ZC, Lian YQ, Qin XQ. 2014. Rocky desertification in Southwest China: impacts, causes, and restoration. Earth-Science Reviews 132: 1-12. 
583 Juan C, Guzik MT, Jaume D, Cooper SJ. 2010. Evolution in caves: Darwin's 'wrecks of ancient 584 life' in the molecular era. Molecular Ecology 19: 3865-3880.

586 Kano Y, Kase T. 2004. Genetic exchange between anchialine cave populations by means of larval 587 dispersal: the case of a new gastropod species Neritilia cavernicola. Zoologica Scripta 33: 423-437.

589 Knez M, Slabe T. 2016. Cave exploration in Slovenia. Cave and karst systems of the world. 590 Springer.

592 Kunz TH, Braun de Torrez E, Bauer D, Lobova T, Fleming TH. 2011. Ecosystem services provided by bats. Annals of the New York Academy of Sciences 1223: 1-38.

595 Lapworth DJ, Baran N, Stuart ME, Warda RS. 2012. Emerging organic contaminants in 596 groundwater: A review of sources, fate and occurrence. Environmental Pollution 163: 287-303.

598 Magnabosco C, Lin LH, Dong H, Bomberg M, Ghiorse W, Stan-Lotter H, Pedersen K, Kieft TL, 599 van Heerden E \& Onstott TC. 2018. The biomass and biodiversity of the continental subsurface. 600 Nature Geoscience 11: 707.

601

602 Mammola S. 2018. Finding answers in the dark: caves as models in ecology fifty years after 603 Poulson and White. Ecography 41: 1-21.

605 Mammola S, Goodacre SL, Isaia M. 2018. Climate change may drive cave spiders to extinction. 606 Ecography 41: 233-243.

608 Mammola S, Leroy B. 2018. Applying species distribution models to caves and other subterranean 609 habitats. Ecography 41: 1194-1208.

611 Medellín RA, Gaona O. 1999. Seed Dispersal by Bats and Birds in Forest and Disturbed Habitats of 612 Chiapas, Mexico 1. Biotropica 31: 478-485. 
615 Medellín RA, Wiederholt R, Lopez-Hoffman L. 2017. Conservation relevance of bat caves for 616 biodiversity and ecosystem services. Biological Conservation 211: 45-50.

618 Moldovan O., Racoviţă Gh., Rajka G. 2003. The impact of tourism in Romanian show caves: the 619 example of the beetle populations in the Urşilor Cave of Chişcău (Transylvania, Romania). 620 Subterranean Biology 1: 73-78.

622 Ng JC, Perry KL. 2004. Transmission of plant viruses by aphid vectors. Molecular Plant Pathology 623 5: $505-511$.

625 Niemiller ML, Zigler KS. 2013. Patterns of cave biodiversity and endemism in the Appalachians 626 and Interior Plateau of Tennessee, USA. PLoS One 8: e64177.

628 Novak T, Šajna N, Antolinc E, Lipovšek S, Devetak D, Janžekovič F. 2014. Cold tolerance in 629 terrestrial invertebrates inhabiting subterranean habitats. International Journal of Speleology 43: $630 \quad 265-272$.

632 Piegay H, Alber A, Slater L, Bourdin L. 2009. Census and typology of braided rivers in the French 633 Alps. Aquatic Sciences 71:371-388.

635 Pipan T, Petrič M, Šebela S, Culver DC. 2018. Analyzing climate change and surface-subsurface 636 interactions using the Postojna Planina Cave System (Slovenia) as a model system. Regional 637 Environmental Change: 1-11.

639 Puechmaille SJ, Gouilh MA, Piyapan P, Yokubol M, Mie KM, Bates PJ, Satasook C, Nwe T, Bu 640 SSH, Mackie JI, Petit JE \& Emma C. Teeling CE. 2011. The evolution of sensory divergence in the 641 context of limited gene flow in the bumblebee bat. Nature Communications 2: 573. 
643 Rabelo LM, Souza-Silva M, Ferreira RL. 2018. Priority caves for biodiversity conservation in a key

644 karst area of Brazil: comparing the applicability of cave conservation indices. Biodiversity and 645 Conservation 9: 1-33.

646

647 Raschmanová N, Šustr V, Kováč L, Parimuchová A, Devette. 2018. Testing the climatic variability 648 hypothesis in edaphic and subterranean Collembola (Hexapoda). Journal of Thermal Biology 78: 649 391-400.

650

651 Reboleira AS, Borges PA, Gonçalves F, Serrano AR, Oromí P. 2011. The subterranean fauna of a 652 biodiversity hotspot region-Portugal: an overview and its conservation. International Journal of 653 Speleology 40: 23-37.

654

655 Reboleira ASPS, Abrantes NA, Oromí P, Gonçalves F. 2013. Acute toxicity of copper sulfate and 656 potassium dichromate on stygobiont Proasellus: general aspects of groundwater ecotoxicology and 657 future perspectives. Water, Air \& Soil Pollution 224: 1550.

658

659 Riddle MR, et al. 2018. Insulin resistance in cavefish as an adaptation to a nutrient-limited 660 environment. Nature 555: 647-651.

661

662 Ripple WJ, Wolf C, Newsome TM, Galetti M, Alamgir M, Crist E, Mahmoud MI, Laurance WF, 66315.364 scientist signatories from 184 countries. 2017. World scientists' warning to humanity: a 664 second notice. BioScience 67: 1026-1028.

665

666 Rizzo V, Sánchez-Fernández D, Fresneda J, Cieslak A, Ribera I (2015). Lack of evolutionary 667 adjustment to ambient temperature in highly specialized cave beetles. BMC evolutionary biology 668 15(1): 10.

669

670 Sánchez-Bayo F, Goka K, Hayasaka D. 2016. Contamination of the aquatic environment with 671 neonicotinoids and its implication for ecosystems. Frontiers in Environmental Science 4: 71. 
673 Schwarzenbach R, Egli T, Hofstetter TB, von Gunten U, Wehrli B. 2010. Global water pollution 674 and human health. Annual Review of Environment and Resources 35: 109-136.

676 Shu SS, Jiang WS, Whitten T, Yang JX, Chen XY. 2013. Drought and China's cave species. 677 Science 340: 272.

679 Soares D, Niemiller ML. 2013. Sensory adaptations of fishes to subterranean environments. 680 BioScience 63(4): 274-283.

682 Souza-Silva M, Martins RP, Ferreira RL. 2015. Cave conservation priority index to adopt a rapid 683 protection strategy: a case study in Brazilian Atlantic rain forest. Environmental Management 55: 684 279-295.

686 Stewart AB, Dudash MR. 2017. Flower-visiting bat species contribute unequally toward 687 agricultural pollination ecosystem services in southern Thailand. Biotropica 49: 239-248.

689 Sugai LSM, Ochoa-Quintero JM, Costa-Pereira R, Roque FO. 2015. Beyond above ground. 690 Biodiversity and Conservation 24: 2109-2112.

691

692 Sutherland WJ, Butchart SHM, Connor B, Culshaw C, Dicks LV, Dinsdale J, Doran H, Entwistle 693 AC, Fleishman E, Gibbons DW, Jiang Z, Keim B, Roux XL, Lickorish FA, Markillie P, Monk KA, 694 Mortimer D, Pearce-Higgins JW, Peck LS, Pretty J, Seymour CL, Spalding MD, Tonneijck FH, 695 Gleave RA. 2018. A 2018 horizon scan of emerging issues for global conservation and biological 696 diversity. Trends in Ecology \& Evolution 33: 47-58.

698 Tanalgo KC, Tabora JA, Hughes AC. 2018. Bat cave vulnerability index (BCVI): A holistic rapid 699 assessment tool to identify priorities for effective cave conservation in the tropics. Ecological 700 Indicators 89: 852-860.

701

702 Taylor RG et al. 2013. Ground water and climate change. Nature Climate Change 3: 322-329. 
704 Teeling EC, Vernes SC, Dávalos LM, Ray DA, Gilbert MTP, Myers E, Bat1K Consortium. 2018.

705 Bat biology, genomes, and the Bat1K Project: To generate Chromosome-Level genomes for all 706 living bat species. Annual Review of Animal Biosciences 6: 23-46.

707

708 Trajano E. 2000. Cave faunas in the Atlantic tropical rain forest: composition, ecology, and 709 conservation. Biotropica 32: 882-893.

711 Trejo-Salazar RE, Eguiarte LE, Suro-Piñera D, Medellin RA. 2016. Save our bats, save our tequila: 712 industry and science join forces to help bats and agaves. Natural Areas Journal 36: 523-531.

714 Trontelj P, Douady C, Fišer C, Gibert J, Gorički Š, Lefébure T, Sket B, Zakšek V. 2009. A 715 molecular test for hidden biodiversity in groundwater: how large are the ranges of macro716 stygobionts? Freshwater Biology 54: 727-744.

718 Valiente-Banuet A, Arizmendi MDC, Rojas-Martínez A, Domínguez-Canseco L, 1996. Ecological 719 relationships between columnar cacti and nectar-feeding bats in Mexico. Journal of Tropical 720 Ecology 12: 103-119. doi:10.1017/s0266467400009330.

722 Voituron Y, de Frapoint M, Issartel J, Guillaume O, Clobert J. 2010. Extreme lifespan of the human 723 fish (Proteus anguinus): a challenge for ageing mechanisms.. Biology Letters 7: 105-107.

725 Wada Y, van Beek LP, van Kempen CM, Reckman JW, Vasak S, Bierkens MF. 2010. Global depletion of groundwater resources. Geophysical Research Letters 37: 402.

728 Whitten T. 2009. Applying ecology for cave management in China and neighbouring 729 countries. Journal of Applied Ecology 46: 520-523.

731 Wilson E. 1992. The Diversity of Life. Belknap Press. 
733 Wisotzky F, Obermann P. 2001. Acid mine groundwater in lignite overburden dumps and its

734 prevention — the Rhineland lignite mining area (Germany). Ecological Engineering 17: 115-123.

735

736 Wynne JJ et al. 2014. Disturbance relicts in a rapidly changing world: the Rapa Nui (Easter Island)

737 factor. BioScience 64: 711-718.

738

739 Wynne JJ, Sommer S, Howarth FG, Dickson BG, Voyles KD. 2018. Capturing arthropod diversity

740 in complex cave systems. Diversity and Distributions 24: 1478-1491.

741

742 Yoshizawa K, Ferreira RL, Kamimura Y, Lienhard C. 2014. Female penis, male vagina, and their

743 correlated evolution in a cave insect. Current Biology 24: 1-5.

745 Yoshizawa, K., Kamimura, Y., Lienhard, C., Ferreira, R. L., \& Blanke, A. 2018a. A biological 746 switching valve evolved in the female of a sex-role reversed cave insect to receive multiple seminal 747 packages. eLife 7: e39563.

749 Yoshizawa M, Settle A, Hermosura M, Tuttle L, Centraro N, Passow CN, McGaugh SE. 2018 b.

750 The evolution of a series of behavioral traits is associated with autism-risk genes in cavefish. BMC 751 Evolutionary Biology 18: 89.

753 Zagmajster M, Culver DC, Christman M, Sket B. 2010. Evaluating the sampling bias in pattern of 754 subterranean species richness: combining approaches. Biodiversity and Conservation 19: 30357553048.

756

757 Zagmajster M, Malard F, Eme D, Culver DC. 2018. Subterranean biodiversity patterns from global 758 to regional Scales. Cave Ecology. Springer. 
Table 1. The eight knowledge shortfalls of subterranean biodiversity (Hortal et al. 2015, Ficetola et subterranean species.

\begin{tabular}{|c|c|c|}
\hline Shortfall & Knowledge gap & Specific problems in subterranean biology \\
\hline Linnean & Species taxonomy & $\begin{array}{l}\text { - Lack of recent estimation of subterranean diversity (see Culver and } \\
\text { Holsinger 1992) } \\
\text { - High prevalence of cryptic species (Delić et al. 2017) } \\
\text { - Bias favouring studies on large versus subterranean microscopic } \\
\text { animals (e.g., meiofauna), or certain taxonomic groups against others } \\
\text { (Zagmajster et al. 2010) }\end{array}$ \\
\hline Wallacean & Species distribution & $\begin{array}{l}\text { - High prevalence of endemic species (Culver and Pipan 2009) } \\
\text { - High prevalence of cryptic species (Eme et al. 2018) } \\
\text { - Lack of global dataset of subterranean species distribution (Culver et } \\
\text { al. 2013) }\end{array}$ \\
\hline Prestonian & Species abundance & $\begin{array}{l}\text { - Lack of reliable estimations due to habitat inaccessibility (see } \\
\text { Racovitzan shortfall) } \\
\text { - Intrinsic bias of most available methods due to low population } \\
\text { densities } \\
\text { - Difficulties on designing capture-mark-recapture experiments due to } \\
\text { the lack of knowledge on life cycles (see Raukiæran shortfall) }\end{array}$ \\
\hline Darwinian & Evolutionary patterns & $\begin{array}{l}\text { - Unknown relationships between many subterranean and surface } \\
\text { lineages (Juan et al. 2010) } \\
\text { - High range of variation in diversification patterns across different } \\
\text { lineages (Juan et al. 2010) } \\
\text { - Difficulty to date diversification events and distinguish among } \\
\text { diversification mechanisms (Morvan et al. 2013) }\end{array}$ \\
\hline Hutchinsonian & Species abiotic tolerance & $\begin{array}{l}\text { - Small population available for experiments } \\
\text { - Breeding species for experiment purposes is often challenging }\end{array}$ \\
\hline Raunkiæran & Species traits & $\begin{array}{l}\text { - Lack of databases of functional traits allowing to predict effect of } \\
\text { impacts on ecosystem level } \\
\text { - Lack of life cycles in most species due to difficulties in monitoring } \\
\text { species populations in its habitats } \\
\text { - Lack of biological traits predicting potential to disperse and colonize } \\
\text { new habitats (e.g., presence of larvae) in freshwater and anchialine } \\
\text { aquatic species (Kano and Kase 2004, Gonzalez et al. 2017) }\end{array}$ \\
\hline Eltonian & Biotic interactions & $\begin{array}{l}\text { - Lack of knowledge on the structure of ecological networks that help } \\
\text { unravel the mechanisms promoting and maintaining subterranean } \\
\text { biodiversity (Mammola 2018) } \\
\text { - Lack of network analyses to calculate the resilience of subterranean } \\
\text { environments upon anthropogenic perturbations }\end{array}$ \\
\hline Racovitzan & Habitat extension & $\begin{array}{l}\text { - The majority of subterranean habitats are not accessible/explorable, } \\
\text { unless by indirect means (Culver \& Pipan 2014, Ficetola et al. 2019, } \\
\text { Mammola 2018) } \\
\text { - Subterranean habitats accessible to humans (e.g., caves) are often } \\
\text { challenging to explore, requiring knowledge on caving techniques and } \\
\text { specific equipment (Zagmajster et al. 2010, Wynne et al. 2018) }\end{array}$ \\
\hline
\end{tabular}


767 Figure 1. Examples of the diversity of life in subterranean habitats. a) Leptodirus hochenwartii

768 Schmidt, 1832 (Coleoptera), the first obligate subterranean invertebrate ever described; b) The 769 subterranean specialized silverfish Squamatinia algharbica Mendes \& Reboleira, 2012 770 (Zygentoma). c) Troglocladius hajdi Andersen et al., 2016 (Diptera), the only specialized 771 subterranean species that have retained functional wings; d) A specialized subterranean microwhip 772 scorpion in the genus Eukoenenia Börner, 1901(Palpigradi)_palpigrads are one of the most 773 enigmatic and understudied orders of arachnids in the world; e) A specialized Troglocheles 774 Zacharda, 1980 (Acari) hunting on a water puddle in a cave; f) A specialized subterranean 775 harvestman in the genus Giupponia Pérez \& Kury, 2002 (Opiliones); g) An eyeless spider Hadites 776 tegenarioides Keyserling, 1862 (Agelenidae); h) The specialized subterranean giant pseudoscorpion 777 Titanobochica magna Zaragoza \& Reboleira, 2010 (Pseudoscorpiones); i) A specialized 778 subterranean crustacean in the genus Spelaeogammarus da Silva Brum, 1975 (Amphipoda); j) An 779 undescribed subterranean isopod from the family Cirolanidae-due to the remarkable 780 depigmentation of this species, internal organs are clearly visible; k) A blind crustacean belonging 781 to the genus Morlockia García-Valdecasas, 1984 (Remipedia)-Remipedia is the latest described 782 class of crustaceans, so far having representatives exclusively in anchialine systems; 1) Marifugia 783 cavatica Absolon \& Hrabe, 1930 (Annelida) - the only freshwater cave-dwelling tube worm in the 784 world; m) The blind tetra, Stygichthys typhlops Brittan \& Böhlke, 1965 (Characidae), one out of the 785 nearly 250 cavefishes described in the world; n) The olm, Proteus anguinus Laurenti, 1768 786 (Amphibia), the first subterranean animal ever described; o) Lessser horseshoe bats Rhinolophus 787 hipposideros Bechstein, 1980 (Rhinolophidae) hibernating in a cave-bats provide critical 788 ecological services and are keystone species in several ecosystems. Photo credits/by courtesy of: a) 789 Dražina T; b, h) Reboleira ASPS; c,l) Bedek J; d) Chiarle A; e) Tomasinelli F; f,i,j,m) Ferreira RL; 790 g) Rožman T; k) Strecker U; n) Krstinić B; o) Biggi E. 